\title{
Review
}

\section{Optical Identification of Middle Ear Infection}

\author{
Alisha Prasad ${ }^{+}$(D) Syed Mohammad Abid Hasan ${ }^{\dagger}$ and Manas Ranjan Gartia * (1) \\ Department of Mechanical and Industrial Engineering, Louisiana State University, Baton Rouge, LA 70803, USA; \\ aprasa9@1su.edu (A.P.); shasan4@1su.edu (S.M.A.H.) \\ * Correspondence: mgartia@lsu.edu \\ † These authors contributed equally to this work.
}

Academic Editor: Kamilla Malek

Received: 31 March 2020; Accepted: 29 April 2020; Published: 9 May 2020

\begin{abstract}
Ear infection is one of the most commonly occurring inflammation diseases in the world, especially for children. Almost every child encounters at least one episode of ear infection before he/she reaches the age of seven. The typical treatment currently followed by physicians is visual inspection and antibiotic prescription. In most cases, a lack of improper treatment results in severe bacterial infection. Therefore, it is necessary to design and explore advanced practices for effective diagnosis. In this review paper, we present the various types of ear infection and the related pathogens responsible for middle ear infection. We outline the conventional techniques along with clinical trials using those techniques to detect ear infections. Further, we highlight the need for emerging techniques to reduce ear infection complications. Finally, we emphasize the utility of Raman spectroscopy as a prospective non-invasive technique for the identification of middle ear infection.
\end{abstract}

Keywords: middle ear infection; bacterial infection; otitis media; otoscope; drug-resistant microbial; label-free method; Raman spectroscopy

\section{Introduction}

Ear infection or otitis media $(\mathrm{OM})$ is a commonly found illness in children under the age of three [1-5]. The healthcare cost due to ear infections in the U.S. is estimated to be $\$ 3-5$ billion annually [6-8]. There are three types of OM, acute otitis media (AOM), otitis media with effusion (OME), and chronic otitis media with effusion [9-13]. AOM occurs in the middle ear due to bacterial infection resulting in the buildup of fluid. OME also results in the buildup of fluid in the middle ear area due to inflammation and is much more severe than AOM. The symptom of both AOM and OME is the swelling of the tympanic membrane (TM). This makes it difficult to diagnose AOM from OME clinically. The typical diagnostic is based on pneumatic otoscopy, which is the gold standard to differentiate AOM from OME [14]. The pneumatic otoscope measures the deflection of TM under pressure by creating an air-tight seal. The response will change when there is fluid buildup behind the TM. In addition to the complicated process of creating an air-tight seal, the pneumatic otoscope can neither identify the bacteria involved in the infection nor distinguish viral infections from bacterial infections. Failure to differentiate viral and bacterial infections and/or AOM from OME may lead to the prescription of antibiotics, leading to drug-resistant microorganisms. Therefore, accurate detection and identification of bacteria responsible for $\mathrm{OM}$ is a clinically unmet need.

The three most common bacteria that are responsible for AOM and OME are Streptococcus pneumoniae (Gram-positive) [15,16], Haemophilus influenza (Gram-negative), and Moraxella catarrhalis (Gram-negative) [17-21]. Humans asymptomatically harbor these bacteria, and they primarily colonize in the upper respiratory tract and scantily populate the lower respiratory tract. These bacteria normally act as symbiotic partners, which ultimately protect the host from getting colonized by possibly more pathogenic or antibiotic-resistant organisms. Fluid buildup in the middle ear with a moist and warm 
environment provides ready access and a well-suited place for bacterial growth and is the main cause of AOM [20]. Acute mastoiditis is another type of bacterial infection resulting from untreated acute otitis media, prompting serious exertion and intrusion of the mastoid cells in the mastoid bone located behind the ear [22]. In current clinical settings, Gram staining is a routine procedure followed, wherein ear swabs are collected for analysis of the bacteria. The major drawback associated with Gram staining is that although it helps in bacterial classification, it gives no information about the bacterial strain. This misinformation may cause the bacterial infection to recur as the prescribed antibiotics might be resistant to the infection. In a recent study, it was found that only in $25 \%$ of the cases, a specific bacteria stain was found in the culture; however, in nearly $80 \%$ of the same cases of OME, the specific DNA-RNA of the pathogens were accurately detected by polymerase chain reaction (PCR) method [19]. This suggest that the combination of molecular biology techniques (like analysis of DNA, RNA, protein) is needed in addition to the microbiology techniques (bacterial staining) for accurate examination of the pathogen. Although these techniques are useful, the main drawbacks include the requirement of specialized expensive equipment, highly skilled lab personnel, and time-consuming sample preparation.

Although most infections are a result of bacterial invasion, there are a few ear infections such as vestibular neuronitis, infectious myringitis, and herpes zoster of the ear, which are caused by viruses. Vestibular neuritis is caused by the inflammation of the vestibular nerve, which is situated at the inner ear (Figure 1a). Acute mastoiditis is a type of bacterial infection resulting from untreated acute otitis media, prompting serious exertion and intrusion of the mastoid cells in the mastoid bone located behind the ear [22]. As seen from Figure 1b, the eardrum of a healthy ear looks pinkish gray, whereas the otitis media infected middle ear in Figure 1c has a red, bulging eardrum.
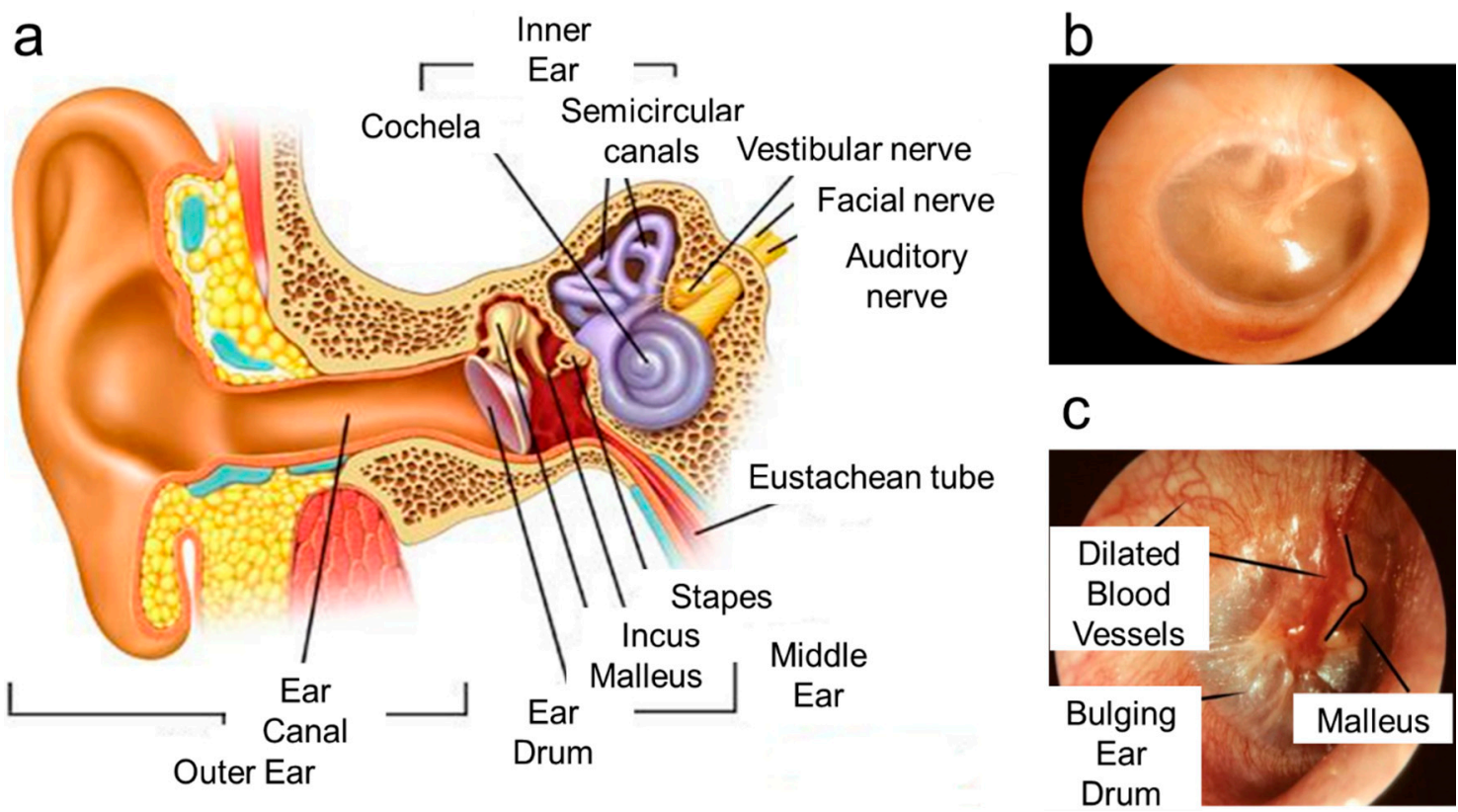

Figure 1. (a) Anatomy of a human ear. Adopted and modified from [9]. (b) Healthy human ear. (c) Infected human ear. Adopted and modified from [23], Copyright Microbiology Society, 2015.

In this manuscript, we reviewed the current and emerging optical techniques useful for the detection of ear infection, and in Table 1, we list them in detail. However, in some cases, the sensitivity and specificity information for ear infection were not found. However, we included the performance parameters for those cases based on the same technology that has been applied in similar fields. Accurate identification of bacteria will provide physicians additional information to prescribe the proper treatment plan while avoiding antimicrobial drug resistance. We also highlighted the Raman 
spectroscopy-based method as a label-free technique with minimal sample preparation to detect and identify bacteria relevant to OM.

Table 1. List of current and emerging optical techniques for the detection of ear infection. OCT, optical coherence tomography; AOM, acute otitis media.

\begin{tabular}{|c|c|c|c|}
\hline Technology & Advantages & Limitations & $\begin{array}{c}\text { Performance } \\
\text { Parameters }\end{array}$ \\
\hline Otoscope & $\begin{array}{l}\text { Visually examines middle ear } \\
\text { including coloration, transparency, } \\
\text { and presence of liquid in the } \\
\text { tympanic membrane. }\end{array}$ & $\begin{array}{l}\text { Visual inspection may not be } \\
\text { enough to detect the type of } \\
\text { infection. }\end{array}$ & $\begin{array}{c}\text { Sensitivity = } \\
61-70 \% \\
\text { Specificity }= \\
61-70 \%[24,25]\end{array}$ \\
\hline Cell Scope & $\begin{array}{l}\text { Visually examines middle ear like } \\
\text { the otoscope with the help of a } \\
\text { cellphone. }\end{array}$ & $\begin{array}{l}\text { Visual inspection with the help } \\
\text { of a cellphone may not detect } \\
\text { the exact type of infection. }\end{array}$ & $\begin{array}{c}\text { Sensitivity }=70 \% \\
\text { Specificity }=70 \% \\
{[26,27] .}\end{array}$ \\
\hline $\begin{array}{l}\text { Terahertz }(\mathrm{THz}) \\
\text { otoscope }\end{array}$ & $\begin{array}{l}\text { Electromagnetic waves sensitively } \\
\text { detect water molecules for feasible } \\
\text { AOM diagnosis. }\end{array}$ & $\begin{array}{l}\text { Terahertz waves are sensitive } \\
\text { to membrane geometry. }\end{array}$ & $\begin{array}{c}* \text { Sensitivity }=82-89 \% \\
* \text { Specificity }=66-77 \% \\
{[28-30] .}\end{array}$ \\
\hline $\begin{array}{l}\text { Acoustic } \\
\text { reflectometry }\end{array}$ & $\begin{array}{l}\text { Measure the fluid formation in the } \\
\text { middle ear. }\end{array}$ & $\begin{array}{c}\text { Limited information for } \\
\text { structural changes in tympanic } \\
\text { membrane. }\end{array}$ & $\begin{array}{c}\text { Sensitivity }=63.6-96 \% ; \\
\text { Specificity }=79.7-87 \% \\
{[31,32] .}\end{array}$ \\
\hline Tympanometry & $\begin{array}{l}\text { Examine the movement of the } \\
\text { eardrum by air pressure. }\end{array}$ & $\begin{array}{l}\text { Structural changes in } \\
\text { tympanic membrane cannot be } \\
\text { detected accurately. }\end{array}$ & $\begin{array}{c}\text { Sensitivity }=70-91 \% \\
\text { Specificity }=71.7-98 \% \\
{[32-34] .}\end{array}$ \\
\hline Pneumatic otoscopy & $\begin{array}{l}\text { Examine the mobility in the } \\
\text { tympanic membrane. }\end{array}$ & $\begin{array}{l}\text { Misinterpretation of diagnosis } \\
\text { and often performed by } \\
\text { untrained personnel. }\end{array}$ & $\begin{array}{c}\text { Sensitivity }=74-94 \% \\
\text { Specificity }=79-80 \% \\
{[25,35] .}\end{array}$ \\
\hline Raman spectrometer & $\begin{array}{l}\text { Determine the unique chemical } \\
\text { fingerprints of molecules } \\
\text { responsible for ear infection. }\end{array}$ & $\begin{array}{l}\text { Sometimes, Raman signals } \\
\text { may need to be enhanced for } \\
\text { better sensitivity of detection. }\end{array}$ & $\begin{array}{l}\text { Sensitivity }=95.48 \% \\
\text { Specificity }=99.06 \%\end{array}$ \\
\hline $\begin{array}{l}\text { Low-coherence } \\
\text { interferometry (LCI) } \\
\text { along with Raman } \\
\text { scattering } \\
\text { spectroscopy (RS) }\end{array}$ & $\begin{array}{l}\text { Identify pathogens of ear } \\
\text { infection. }\end{array}$ & $\begin{array}{l}\text { Bacterial pathogens in body } \\
\text { fluid cannot be detected. }\end{array}$ & Not available. \\
\hline $\begin{array}{l}\text { Low-coherence } \\
\text { interferometry/optical } \\
\text { coherence } \\
\text { tomography }\end{array}$ & $\begin{array}{l}\text { Non-invasive; causes no tissue } \\
\text { damage, and suitable for in vivo } \\
\text { applications. }\end{array}$ & $\begin{array}{l}\text { Sometimes, the beam focus } \\
\text { cannot reach to the long ear } \\
\text { canal; thus, it delivers } \\
\text { inadequate signal-to-noise } \\
\text { ratio data. }\end{array}$ & $\begin{array}{c}\text { Sensitivity }= \\
68-86 \% \\
\text { Specificity }=90-98 \% \\
{[1,36] .}\end{array}$ \\
\hline $\begin{array}{l}\text { Diffuse reflectance } \\
\text { spectroscopy }\end{array}$ & $\begin{array}{l}\text { Measure the hemoglobin content } \\
\text { of the tympanic membrane. }\end{array}$ & $\begin{array}{l}\text { May not be suitable for in vivo } \\
\text { experiment. }\end{array}$ & $\begin{array}{c}* \text { Sensitivity }=89-100 \% ; \\
\text { Specificity }=79-100 \% \\
{[37,38] .}\end{array}$ \\
\hline $\begin{array}{l}\text { Reflectance and } \\
\text { scattering absorption } \\
\text { spectroscopy }\end{array}$ & $\begin{array}{l}\text { Analyze the gases and also } \\
\text { determine the oxygen flow in the } \\
\text { eardrum. }\end{array}$ & $\begin{array}{l}\text { Experiments were done on ear } \\
\text { phantom and planning to be } \\
\text { performed in clinical trials } \\
\text { soon. }\end{array}$ & Not available. \\
\hline $\begin{array}{l}\text { Fluorescence } \\
\text { otoscope }\end{array}$ & $\begin{array}{l}\text { A platform for fluorescence } \\
\text { imaging of congenital } \\
\text { cholesteatomas (i.e., } \\
\text { non-cancerous skin growth) found } \\
\text { in the middle ear tissue. }\end{array}$ & $\begin{array}{l}\text { Difficult to get proper } \\
\text { signal-to-noise ratio for weak } \\
\text { fluorescent features. }\end{array}$ & $\begin{array}{c}* \text { Sensitivity }=96.7 \% \\
\text { Specificity }=91.7 \% \\
\text { [39]. }\end{array}$ \\
\hline Hand-held OCT & $\begin{array}{l}\text { Provide quantitative information } \\
\text { about the biofilm progression in } \\
\text { cases of middle ear infection. }\end{array}$ & $\begin{array}{l}\text { Acquiring full } \\
\text { three-dimensional in vivo } \\
\text { imaging is difficult. }\end{array}$ & $\begin{array}{c}\text { Sensitivity }=68-90.9 \% \\
\text { Specificity }=90.2-98 \% \\
{[1,40]}\end{array}$ \\
\hline $\begin{array}{c}\text { SWIR (short } \\
\text { wavelength infrared) } \\
\text { otoscope }\end{array}$ & $\begin{array}{l}\text { Analyze the anatomical structures } \\
\text { situated after the thin tissue } \\
\text { membranes inside the ear such as } \\
\text { an ear drum. }\end{array}$ & $\begin{array}{l}\text { Some supplementary training } \\
\text { is required for the medical } \\
\text { practitioners. }\end{array}$ & $\begin{array}{c}\text { Sensitivity }=* 67-100 \% \\
\text { Specificity }=89-100 \% \\
{[41] .}\end{array}$ \\
\hline $\begin{array}{l}\text { Confocal laser } \\
\text { scanning microscopy } \\
\text { (CLSM) }\end{array}$ & $\begin{array}{l}\text { Detect biofilm-related middle ear } \\
\text { pathogens. }\end{array}$ & $\begin{array}{l}\text { Detecting biofilm in adenoid is } \\
\text { a challenging task. }\end{array}$ & $\begin{array}{c}\text { * Sensitivity }= \\
85.19-98.15 \% ; \\
\text { Specificity }= \\
97.6-99.26 \%[42,43] .\end{array}$ \\
\hline
\end{tabular}

* Refers to a similar technology, but not specifically applied to detect ear infection. 


\section{Clinical Imaging Techniques for the Identification of Otitis Media}

Clinically, an otoscope is the most widely used device by an otolaryngologist for identification of problems associated with ear pain. The key parameters examined in the middle ear include coloration, transparency, and the presence of liquid in the tympanic membrane [14]. In most cases, patients are advised oral or topical antibiotics; although being sufficient for pain, the infection recurs due to the evolution of antimicrobial-resistant bacteria. It has been found that the frequent use of antibiotics and bacterial biofilms can help to increase antimicrobial resistance [44,45]. Recently, Yang et al. developed an antibiotic-encapsulated hydrogel with chemical permeation enhancers to improve the drug efficiency and antimicrobial therapy of the hydrogel, when applied to the tympanic membrane through the external auditory canal of the ear. The formulated hydrogel successfully eradicated AOM from the Haemophilus influenzae bacteria in a chinchilla model [46]. A single dosage of such drugs would cover a complete antibiotic course, improving patient compliance, avoiding antibiotic over-dosage, and ultimately reducing recurrent side effects. Figure 2a (left) shows a typical otoscope, and Figure 2a (right) shows an iPhone-enabled otoscope (Cell Scope). Monroy et al. mentioned that an otoscope showed approximately $70 \%$ sensitivity and specificity for diagnosis of otitis media [24]. Although both the otoscope and CellScope are useful tools, visual inspection alone may not be sufficient to detect the specific type of infection, in more severe cases. AOM is associated with inflammatory changes, such as variations in the mucous membrane, accumulation of liquid, and pus. Some visual observation can be made with the otoscope; however, any chemical changes or identification of bacterial phenotype are not possible with a conventional otoscope. Ji et al. designed and constructed a terahertz $(\mathrm{THz})$ otoscope, which works on $\mathrm{THz}$ technology or in other words electromagnetic waves to detect water molecules sensitively for feasible AOM diagnosis. The detection of electromagnetic waves enabled by the terahertz technology is helpful for obtaining precise ear membrane information. Figure $2 b$ shows the schematics of a THz otoscope, which is integrated with a conventional optical otoscope with a fiber-coupled $\mathrm{THz}$ module. It was interesting to see that this device can be used as both a $\mathrm{THz}$ otoscope, as well as a conventional otoscope. While $\mathrm{THz}$ technology has been used in several biomedical applications, this technology helps the physician diagnose AOM as well. From their results, it was evident that it was possible to identify the presence of water located at the membrane and sample interface with respect to different types of $\mathrm{THz}$ pulses regulated by membrane thickness and separate refractive indices [47].
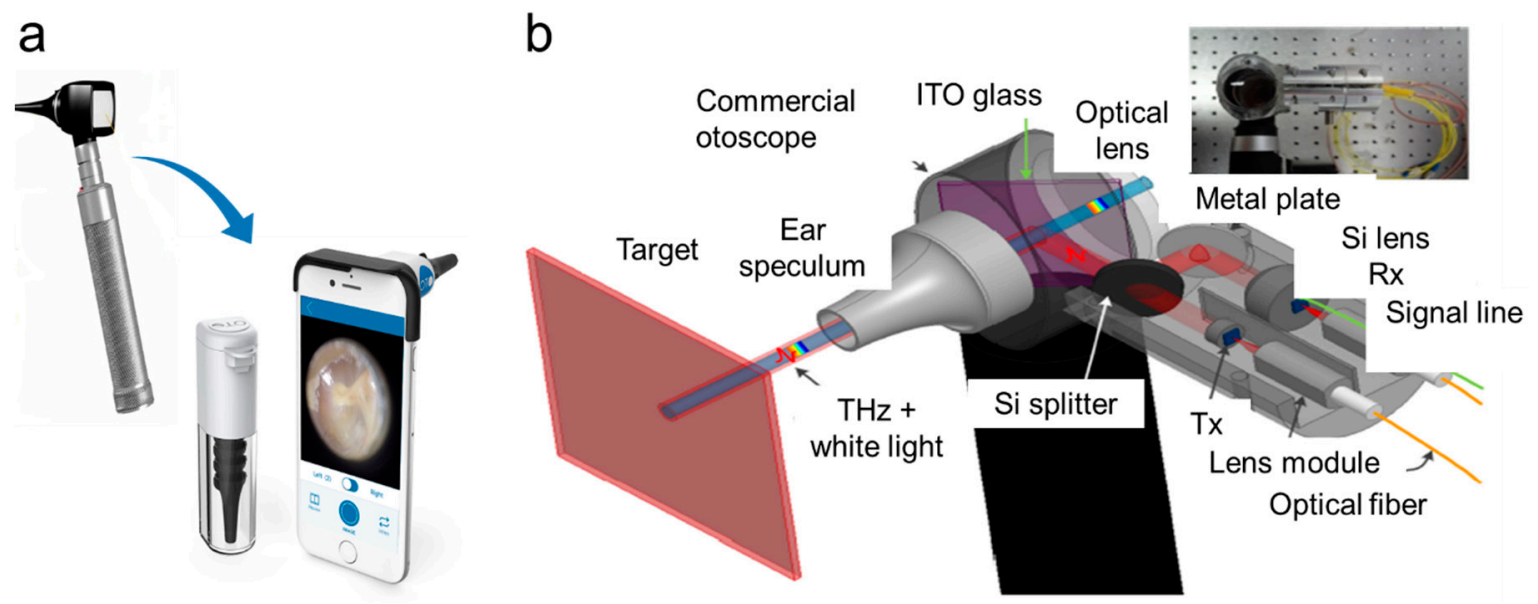

Figure 2. Clinically available tools to detect middle ear infection. (a) CellScope; (b) terahertz otoscope [47].

A few other clinical methods for the diagnosis of otitis media and otitis media-related infections include acoustic reflectometry, tympanometry, and pneumatic otoscopy. Acoustic reflectometry is used to measure the fluid formation in the middle ear and has $63.6-96 \%$ sensitivity and $79.7-87 \%$ 
specificity [31,32]. Tympanometry is used to examine the movement of the eardrum by air pressure and has 70-91\% sensitivity and 71.7-98\% specificity [32-34]. Pneumatic otoscopy is used to examine the mobility in the tympanic membrane with diagnostic accuracy (percent of total test items correct) of about $76 \%$. Pneumatic otoscopy showed $24 \%$ improvement in sensitivity and $42 \%$ improvement in specificity, compared to a conventional otoscope [25]. However, Sundvall et al. reported the sensitivity and specificity of pneumatic otoscopy as $94 \%$ and $80 \%$, respectively [27,35]. According to a clinical chronic ear survey (CES), it was found that in nearly $25-50 \%$ of cases of ear inspection, otolaryngologists do not use pneumatic otoscopes, while the ergonomic survey reveals that in most of the remaining cases, nearly $43 \%$ of pneumatic diagnosis are misinterpreted and performed by untrained personnel [48]. However, these three techniques-pneumatic otoscopy, acoustic reflectometry, and tympanometry-have a common limitation, as they cannot provide complete depth-resolved statistics regarding the structural variations at the tympanic membrane. Furthermore, if any kind of biofilm has formed behind the tympanic membrane, it will not be detected properly by these techniques [49].

\section{Preclinical Imaging Techniques for the Identification of Otitis Media}

Optical-based diagnostics, which utilize the properties and behavior of light to obtain information about the structure and properties of matter, is emerging as a powerful technique for various biomedical examinations. Although there are a few scientific publications exploring optical imaging for middle ear evaluation, in clinical settings, they have generally been unexplored. To date, no technique manages to replicate or surpass otoscopic clinical capabilities. In this section, we cover published reports on optical imaging of middle ear pathologies. For example, Raman spectroscopy is a label-free method that utilizes the light scattering phenomena to determine the unique chemical fingerprints of any molecule by probing individual chemical bond vibrations [50]. According to the literature, the Raman spectrometer has been utilized extensively for identifying single bacteria cells or bacterial colonies based on the acquired Raman spectra [51-54]. Recently, several researchers have also exploited Raman spectroscopy for identification and detection of pathogens in ear infection cases. For example, in a recent study, a Raman spectrometer was used to understand the middle ear pathology and analyze the molecular peaks from the collected spectra [55]. They found the sensitivity and specificity to be $95.48 \%$ and $99.06 \%$, respectively, from their experiment. However, one of the limitations of the Raman spectrometer is the weak signal, and by enhancing the signal, detection sensitivity can be improved [56]. Zhao et al. also developed a combinatorial platform assembling low-coherence interferometry (LCI) along with Raman scattering spectroscopy (RS) to identify pathogens relevant to ear infection. Figure 3a shows a schematic representation of their assembly. The LCI helps to distinguish and detect depth-resolved structural evidence of the pathogens, while the Raman spectrometer provides non-invasive molecular evidence. Together, they help to improve the diagnostic capability for identification of middle ear infection (or AOM) in real-time. On the other hand, this technology cannot detect bacteria pathogens in body fluid as it requires them to be restricted to a limited area of the microscope [56]. In another similar study, Rebrosova et al. utilized a Raman spectrometer to detect Staphylococcal species $(\mathrm{n}=16)$ from bacterial colonies. Such studies could be applied for the identification of the Staphylococcal type of bacteria found prominently in ear infection patients [57-62]. Raman spectroscopy is a challenging technique, as the Raman spectra are generated from numerous molecular constituents of the target. Hence, the global spectral features of a single bacteria or bacterium would ideally show peaks within a certain range for biomolecules such as proteins (amide bonds), lipids, carbohydrates, and nucleic acids (polypeptide backbone) [63]. This information is shown in Figure 3b, and the Raman band assignments of these common bacteria of ear infection are tabulated in Table 2. 
a
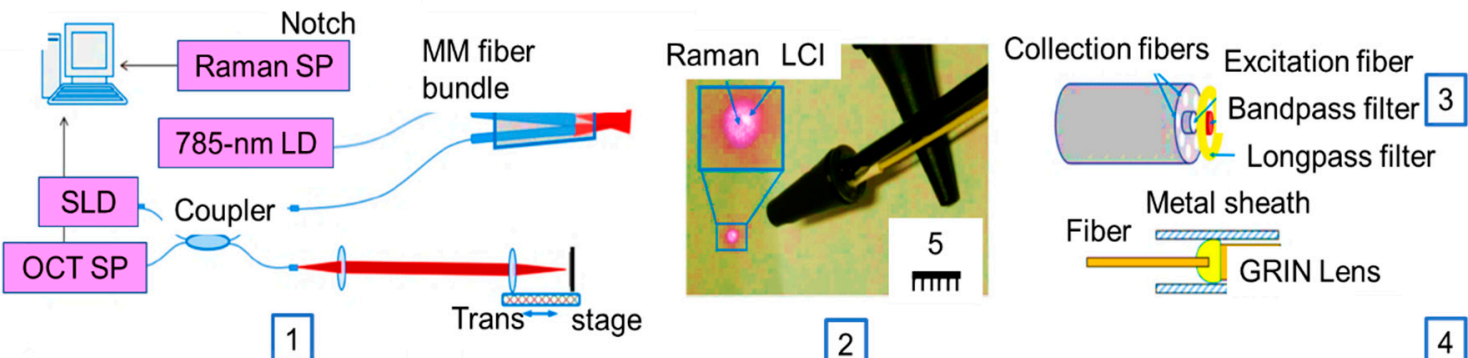

2

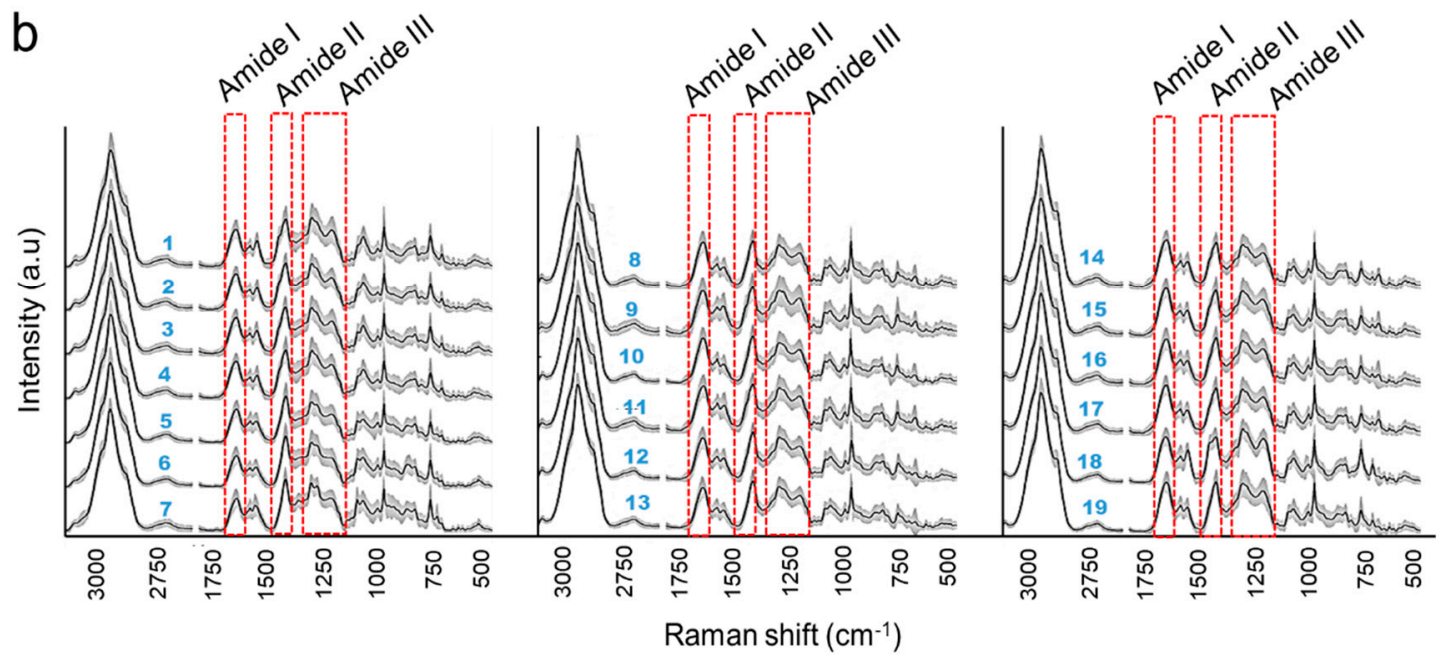

Figure 3. (a) Raman and low-coherence interferometry (Raman LCI) ((gradient index (GRIN); spectrometer (SP); laser diode (LD); superluminescence diode (SLD); multimode (MM)). Reproduced with permission from [56]. (b) Mean Raman spectra of common bacteria of ear infection. 1: Listeria grayi, 2: Listeria innocua, 3: Listeria monocytogenes, 4: Listeria welshimeri, 5: Staphylococcus aureus, 6: Staphylococcus cohnii, 7: Staphylococcus epidermidis, 8: Escherichia coli, 9: Pseudomonas aeruginosa, 10: Pseudomonas putida, 11: Pseudomonas stutzeri, 12: Salmonella enterica, 13: Salmonella typhimurium, 14: Yersinia aldovae, 15: Yersinia bercovieri, 16: Yersinia enterocolitica, 17: Yersinia mollaretii, 18: Yersinia rohdei, 19: Yersinia ruckeri. Adopted and modified with permission from [64]. Copyright Elsevier Ltd., 2013.

Table 2. Raman spectra and band assignments observed in common pathogens such as S. pneumoniae, H. influenzae, P. aeruginosa, Moraxella, Streptococcus pyogenes, and Staphylococcus aureus [58-61,64].

\begin{tabular}{|c|c|}
\hline Range $\left(\mathrm{cm}^{-1}\right)$ & Peak Assignment \\
\hline $640-675$ & Guanine (B-DNA), tyrosine valine \\
\hline $713-740$ & Adenine, glycoside \\
\hline $745-790$ & Cytosine, uracil, thymine, tryptophan \\
\hline $800-815$ & $\mathrm{O}-\mathrm{P}-\mathrm{O}(\mathrm{RNA})$ \\
\hline $930-990$ & C-C stretch ( $\alpha$-helix skeletal mode), $\mathrm{C}-\mathrm{N}$ stretch \\
\hline $1000-1010$ & Phenylalanine, $\mathrm{C}-\mathrm{C}$ aromatic ring stretch \\
\hline $1025-1060$ & C-C stretch (phospholipids, glucosidic rings), C-N stretch \\
\hline $1080-1105$ & $\mathrm{PO}^{2-} / \mathrm{O}-\mathrm{P}-\mathrm{O}(\mathrm{DNA}), \mathrm{CO}_{3}{ }^{2-} / \mathrm{C}-\mathrm{C}$ or $\mathrm{C}-\mathrm{O}-\mathrm{C}$ stretching (carbohydrates) \\
\hline $1130-1145$ & $\mathrm{C}-\mathrm{O}-\mathrm{C}$ (unsaturated fatty acids) \\
\hline $1215-1295$ & Amide III (random), thymine phenylalanine, tryptophan \\
\hline $1330-1345$ & Adenine, guanine, $\mathrm{C}-\mathrm{H}$ stretch \\
\hline $1390-1415$ & COO- symmetric stretch \\
\hline 1440-1475 & $\mathrm{CH}_{2}$ deformation \\
\hline $1510-1560$ & Amide II $(\mathrm{C}=\mathrm{C})$ \\
\hline $1570-1595$ & Adenine, guanine (ring stretching), nuclei acid bands \\
\hline $1658-1700$ & Amide I \\
\hline $2890-2900$ & $\mathrm{C}-\mathrm{H}$-stretching deformation vibrations of $\mathrm{CH}_{2}$ and $\mathrm{CH}_{3}$ \\
\hline
\end{tabular}


These Raman peaks are helpful in identifying the pathogen; however, classifying these pathogenic strains as per the nomenclature is challenging without statistical analysis. Therefore, researchers have used multivariate analysis to define, differentiate, and classify the constituent peaks from the bacteria to detect clinically relevant information with precise specificity [65]. In a similar study, Pandey et al. used Raman spectroscopy to image myringosclerosis, a pathologic condition arising due to calcium deposits on the tympanic membrane, and to understand the molecular characteristics of these whitish, sclerotic plaques [66]. Similarly, Ayala et al. used an in vivo confocal assisted Raman microscope to analyze and study the profile of three commonly found bacteria, Haemophilus influenzae, Moraxella catarrhalis, and Streptococcus pneumonia grown on agar plates which are responsible for acute otitis media (AOM) [20]. Their group also conducted an extensive study on Staphylococcus aureus using Raman spectroscopy, to understand the antibiotic resistance capability of this species from the acquired Raman peaks [67]. In 2018, Boppart et al. developed and patented a Raman handheld device to detect microbiological constituents of the middle ear from the collected Raman spectrum [68]. This handheld Raman tool can serve as a point-of-care device providing the potential for label-free, non-invasive, real-time identification and detection of ear contagions.

Besides Raman spectroscopy, several other optical systems have been constructed lately. In this section, we present some of the notable works using emerging optical platforms for diagnosis of ear infection. For example, Sundberg et al. used diffuse reflectance spectroscopy, an infrared spectroscopy technique, to measure the hemoglobin content of the tympanic membrane in children to find whether or not they were affected with otitis media [69]. Figure 4a shows the schematic of their assembled setup, which included a probe head along with its illumination and detector fibers. Because the tympanic membrane is well supplied with blood vessels and sensory nerve fibers, the oxygenated hemoglobin peaks could be recorded at $542 \mathrm{~nm}$ and $576 \mathrm{~nm}$, respectively. The hypothesis of their study was that the diffuse reflectance spectra from a healthy and an erythematous tympanic membrane ought to differ analogously with the spectra. This method is fast and non-invasive, making it very advantageous and competitive for in vivo measurements over other optical methods. However, their probe design may not be suitable for in vivo experiments for conscious children.

Scientists have also constructed ear phantoms to understand the acoustic transmission in the internal ear cavities. The middle ear cleft contains two capillary vessels: one with arterial blood takes away oxygen $\left(\mathrm{O}_{2}\right)$, while the vessels with venous blood escalates the carbon dioxide $\left(\mathrm{CO}_{2}\right)$ and water vapor $\left(\mathrm{H}_{2} \mathrm{O}\right)$ from the air at the fork. Because of the anatomy of the middle ear, this circulation is in the order of a few minutes such that the partial pressure of these gases in air and the blood vessels is equal [70]. This gas exchange mechanism has been used to explore different regions of the air-filled middle ear cavities such as the tympanic membrane caries, aditus, antrum, and the mastoid air cell system [71]. Recently, Zhang et al. developed a noninvasive optical method by combining reflectance and scattering absorption spectroscopy. In their setup, absorption spectroscopy was utilized for analyzing the gases by collecting the backscattered light through a fiber-optics probe, while the diffuse reflectance spectra were used simultaneously to determine the oxygen flow in the eardrum with a reflectance probe [9]. The combined spectroscopic approach was very convincing because the absorption marks of gases were nearly $10^{4}$ times finer compared to immediate solid constituents, providing a high accuracy of diagnosis. They recently improved their performance of detection by using a more realistic phantom compared to the previous studies, but clinical trials are yet to be performed in the near future [72].

Besides pneumatic assessment to differentiate healthy and diseased ear sections, based on single wavelength transmission, researchers have also explored multi-wavelength based imaging strategies. A few advantages of a multi-wavelength imaging system in comparison to the latter include the ability to obtain high-resolution cell images with reduced flare and low signal-to-noise ratio irregularities. For almost a century and to date, white light otoscopes were/are used extensively for the identification of external auditory canal and middle ear pathologies. Recently, Valdez et al. coupled the conventional otoscope with multiwavelength fluorescent filters and a CMOS camera to record videos of the 
ear infections. Figure $4 \mathrm{~b}$ (top) shows the block diagram of their design, and Figure $4 \mathrm{~b}$ (bottom) shows the images of the middle ear and tympanic membrane by using white light otoscopy and fluorescence imaging acquired at two different excitations ( $405 \mathrm{~nm}$ and $450 \mathrm{~nm}$, respectively). Their team demonstrated this proof-of-concept platform for fluorescence imaging of congenital cholesteatomas (i.e., non-cancerous skin growth) found in the middle ear tissue. This assembled otoscope brought together a portable, adaptable, low-cost, feasible fluorescence imaging device for clinical identification of middle ear pathologies. However, their system was limited to the gain signal from the brightest chromophores, and it was difficult to get a proper signal-to-noise ratio for weak fluorescent features [73]. Studies have also been reported on applying non-contact optical sensing techniques or optical scattering techniques by using low-coherence light to obtain 2D/3D images of biological tissues/sections in micron resolution. This imaging technique is widely known as optical coherence tomography (OCT) or low-coherence interferometry (LCI). Nguyen et al. integrated these techniques to identify infected and non-infected ear based on light scattering phenomena arising from the middle ear biofilms [1]. Their research group also integrated LCI with a video otoscope to quantify the biofilms in an animal model based on the developed algorithm code [36]. The advantages of OCT are that it is non-invasive, causes no tissue damage, and is suitable for in vivo applications [74]. However, due to the long ear canal, sometimes, it is difficult to get a proper signal-to-noise ratio from the LCI/OCT setup as the beam focus is not able to reach there [1]. Near-infrared OCT has been demonstrated to detect middle ear biofilms by penetrating through the tissues of an ear with ultra-high-resolution up to nearly $1.3 \mu \mathrm{m}$ and generating 3D images for visualization [75]. Jung et al. and Nguyen et al. were the forerunners in this area of research and also assembled a portable, handheld OCT system, as shown in Figure 5a. Their OCT setup contained a broadband source to generate low-coherence light, a fiber coupler for splitting two beams, and transferring it to the interferometer, a linear photodetector that captured the scattered beams, and a computer for data acquisition. They utilized this OCT system to detect bacterial biofilms accumulated in the eardrum. However, acquiring complete three-dimensional imaging is still a challenge for their system [76,77]. While a clinical otoscope only provided subjective or qualitative diagnosis, the assembled handheld OCT provided quantitative information about the biofilm progression in cases of middle ear infection. OCT has also been applied to understand AOM and chronic cases of otitis media in the tympanic membrane [75]. Besides AOM identification, several studies have also utilized the handheld OCT for scanning biofilms from the tympanic membrane [1,77-79]. By combining a fiber based device with OCT, Boppart et al. studied possible reasons for the formation of fluid behind the ear drum as a result of otitis media with effusion [80].
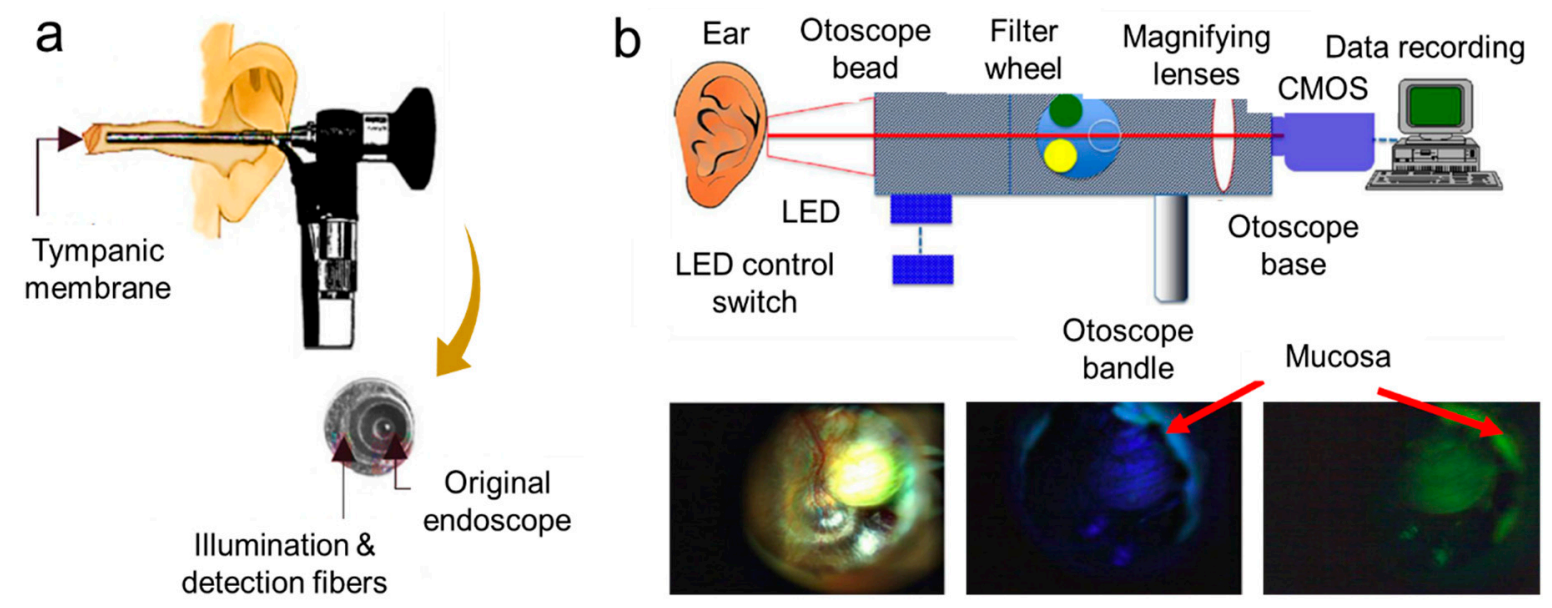

Figure 4. Tools available to detect middle ear infection. (a) Diffuse reflectance spectroscopy. Reproduced with permission from [68]. Copyright IOP Publishing, 2017. (b) Fluorescence otoscope. Reproduced with permission from [72], Copyright American Chemical Society, 2014. 


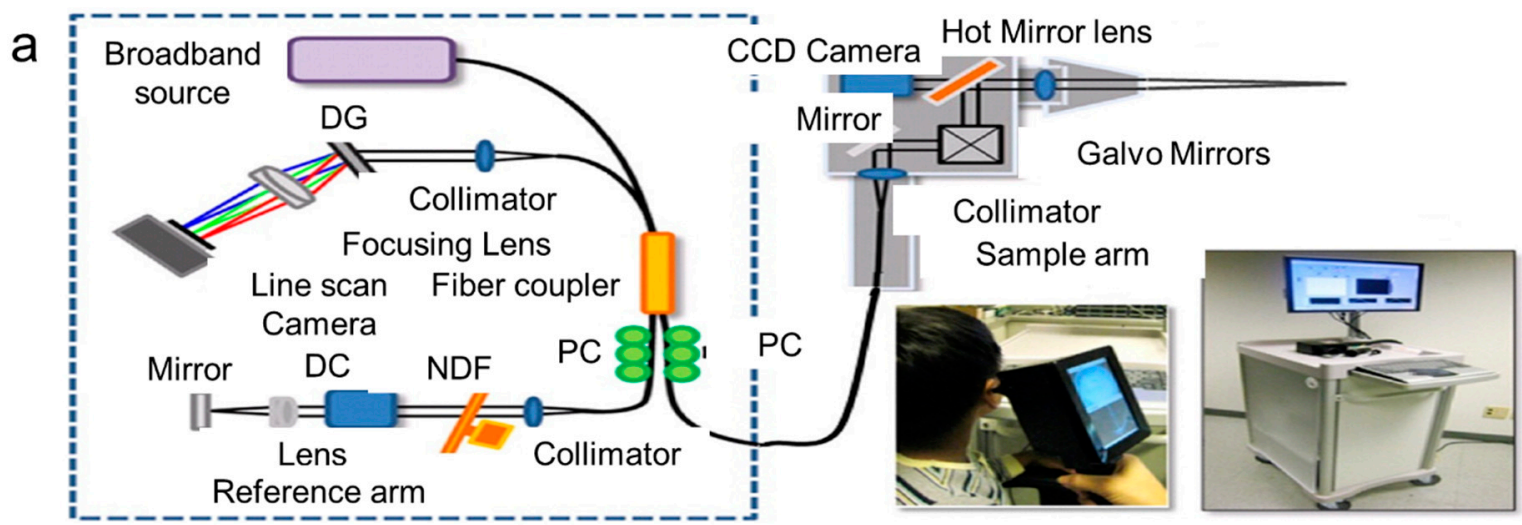

b
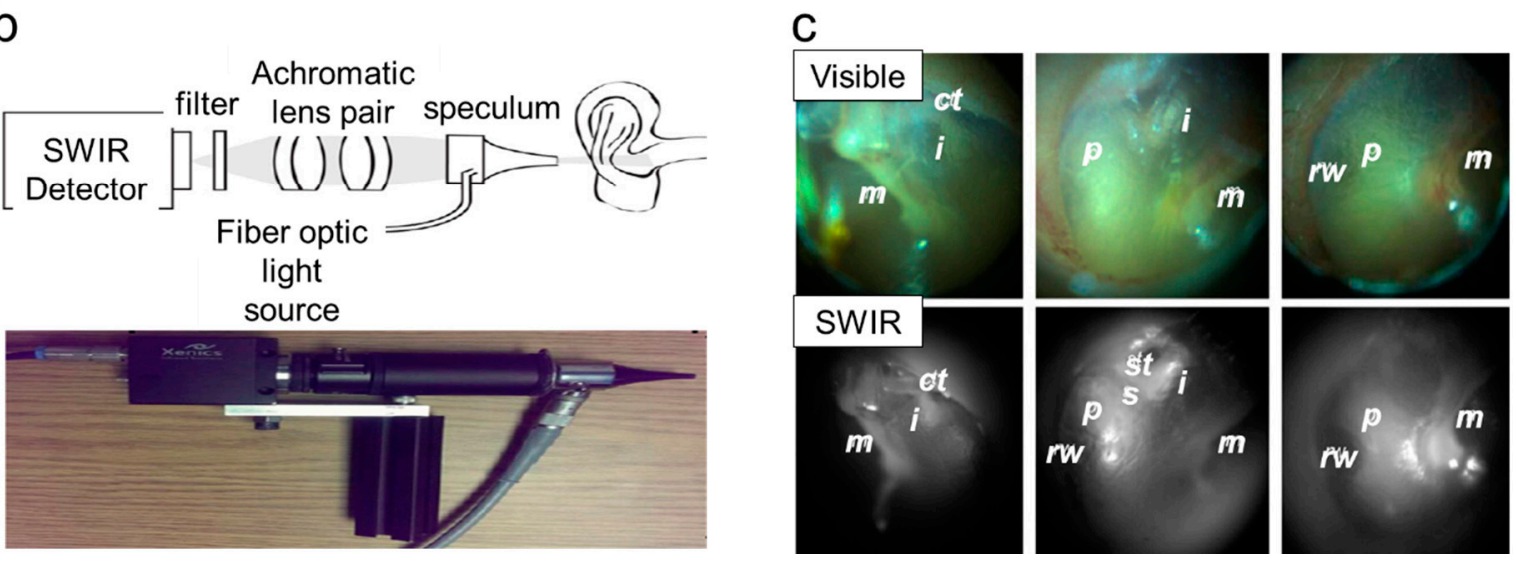

Figure 5. Tools available to detect middle ear infection. (a) Handheld OCT (optical coherence tomography) (diffraction grating (DG); polarization controller (PC); dispersion compensation (DC) materials; neutral density filter (NDF)). Reproduced with permission from [76]. Copyright Elsevier B.V.,2013. (b) SWIR (short wavelength infrared) otoscope. Reproduced with permission from [81]. Copyright National Academy of Sciences,2016 (c) Representative images for (b) Reproduced with permission from [81]. Copyright National Academy of Sciences,2016. ct, chorda tympani; i, incus; m, malleus; p, cochlear promontory; st, stapedial tendon; s, stapes; rw, round window niche.

The clinical otoscope has a single white light source only, which limits its applicability from an optical imaging standpoint. To overcome this, Carr et al. used short wave infrared (SWIR) light combined with an otoscope to analyze the anatomical structures situated after the thin tissue membranes inside the ear such as the ear drum [81]. SWIR covers the wavelength from 1.4 to 3 microns in the electromagnetic spectrum and as a result can often offer increased penetration and better image resolution that is otherwise not achievable with visible light imaging. In Figure $5 b$, we show the schematic of their SWIR system, which includes a fiber-coupled light source, a pair of achromatic doublet lenses, a disposable medical speculum, an indium gallium arsenide (InGaAs) sensor, and an SWIR detector. As shown in Figure 5c, they compared SWIR otoscope-acquired images with visible images and successfully identified the chorda tympani, cochlear promontory, malleus, stapedial tendon, incus, stapes, and round window niche (indicated by their initials as shown in the images). Even though their system was very much viable to image middle ear pathologies, sometimes it may require some supplementary training of the medical practitioners. In another similar study, Schaefer et al. also suggested an infrared light source for thermography for early recognition of various infections, not only in ears, but also other facial areas [82].

Confocal laser scanning microscopy (CLSM) is another emerging real-time in vivo imaging system. Hall-Stoodley used CLSM to obtain middle-ear mucosa biopsy specimens and concluded that otitis media was biofilm related [19]. On the other hand, Tang et al. used CLSM and identified three common bacteria, namely H. influenzae, S. pneumoniae, and M. catarrhalis, by using a fluorescent dye and a 
bacterial targeting ligand, Concanavalin A [83]. Similarly, Hoa et al. used confocal laser scanning microscopy (CLSM) to detect middle ear pathogens in biofilms obtained from the nasal cavities [84]. The bacteria type was identified by using type-specific $16 \mathrm{~S}$ ribosomal RNA labeled with Cy3 and Cy5 fluorescent dyes, respectively. However, detecting biofilm in adenoid is a challenging task by using CLSM, and the role of adenoid biofilm in ear infection is very significant $[84,85]$.

In recent years, more focus has been devoted towards building point-of-care devices/technology, for example handheld OCT or handheld Raman probes, for easy, handy, and accurate diagnosis in clinical or non-clinical settings $[77,78,86]$.

\section{Clinical Trials Using the Optical Imaging Techniques}

Although the data in clinical trials are limited due to the tedious investigation protocols, number of subjects, and patient consent issues, we have listed a few published reports on Phase II clinical trials (in Table 3) wherein the number of patients/participants observed were greater than 10 . We also categorized these approaches based on the device/technology used, brief objectives, and main findings. These clinical trials suggested that an otoscope is the most used medical device by healthcare professionals (e.g., physicians, nurse practitioners, audiologists) to screen or diagnose patients with ear infection followed by tympanometry and optical coherence tomography.

Table 3. List of Phase II clinical trials for ear infection detection.

\begin{tabular}{|c|c|c|c|c|c|}
\hline Technology & & Objective & Main Observations & $\begin{array}{l}\text { No. of } \\
\text { Patients } \\
\text { Observed }\end{array}$ & Authors \\
\hline $\begin{array}{l}\text { Otoscope with } \\
\text { cellphone: } \\
\text { CellScope Oto } \\
\text { (CSO) }\end{array}$ & $\bigcirc$ & $\begin{array}{l}\text { Used for diagnosis of the } \\
\text { tympanic membrane. } \\
\text { Handy, easy to use, } \\
\text { good precision. }\end{array}$ & $\begin{array}{l}\text { Physicians, patients, and parents } \\
\text { favored CellScope Oto in } \\
\text { comparison to the conventional } \\
\text { otoscope as it was easy to use, had } \\
\text { good diagnostic precision, with the } \\
\text { benefit of image acquisition } \\
\text { to track changes through the period } \\
\text { of infection. }\end{array}$ & 51 (adults) & $\begin{array}{l}\text { Richards } \\
\text { et al. [87] }\end{array}$ \\
\hline SWIR otoscope & $\bigcirc$ & $\begin{array}{l}\text { Used for examination of the } \\
\text { tympanic membrane and to } \\
\text { identify fluid accumulation } \\
\text { in the middle ear. } \\
\text { The infrared transmission } \\
\text { provides better visibility of } \\
\text { the anatomical components } \\
\text { of the inside ear. }\end{array}$ & $\begin{array}{l}\text { SWIR facilitated non-invasive } \\
\text { optical penetration to image } \\
\text { deep ear tissues and identify fluid } \\
\text { accumulation in the middle ear, } \\
\text { which is otherwise difficult to } \\
\text { visualize from a conventional } \\
\text { otoscope. }\end{array}$ & 10 (adults) & $\begin{array}{c}\text { Carr et al. } \\
\text { [81] }\end{array}$ \\
\hline Otoscope & $\bigcirc$ & $\begin{array}{l}\text { Used for routine checkup } \\
\text { from parent-reported } \\
\text { symptom for children with } \\
\text { AOM (AOM-SOS). }\end{array}$ & $\begin{array}{c}\text { Due to a lack of techniques to track } \\
\text { early symptoms in children with } \\
\text { AOM, a parent-reported AOM } \\
\text { severity of symptoms (AOM-SOS) } \\
\text { structured questionnaire was } \\
\text { established to understand the AOM } \\
\text { symptoms for better treatment } \\
\text { trials. }\end{array}$ & 264 (children) & $\begin{array}{l}\text { Shaikh et } \\
\text { al. [88] }\end{array}$ \\
\hline Otoscope & $\bigcirc$ & $\begin{array}{l}\text { Used to identify otitis media } \\
\text { from endoscopic still images } \\
\text { of the tympanic membranes. }\end{array}$ & $\begin{array}{l}\text { To understand AOM diagnosis, } \\
\text { endoscopic still images of the } \\
\text { tympanic membrane were } \\
\text { examined by expert otoscopists. } \\
\text { Preventive antibiotic treatment was } \\
\text { the individual-advised diagnostic } \\
\text { criteria. }\end{array}$ & 783 (children) & $\begin{array}{l}\text { Shaikh et } \\
\text { al. [89] }\end{array}$ \\
\hline $\begin{array}{l}\text { Pneumatic } \\
\text { otoscope }\end{array}$ & $\bigcirc$ & $\begin{array}{l}\text { Used for routine analysis to } \\
\text { check for dullness or reflex } \\
\text { from the tympanic } \\
\text { membrane in newborns. }\end{array}$ & $\begin{array}{l}\text { This study revealed the general ear } \\
\text { features in healthy newborns }(\sim 72 \mathrm{~h} \\
\text { of life), mostly having pink/red } \\
\text { colored eardrums, with a dull } \\
\text { gray/opaque tympanic membrane. }\end{array}$ & 81 (newborn) & $\begin{array}{l}\text { Cavanaugh } \\
\text { et al. [90] }\end{array}$ \\
\hline
\end{tabular}


Table 3. Cont.

\begin{tabular}{|c|c|c|c|c|c|}
\hline Technology & & Objective & Main Observations & $\begin{array}{c}\text { No. of } \\
\text { Patients } \\
\text { Observed }\end{array}$ & Authors \\
\hline Otoscope & $\bigcirc$ & $\begin{array}{l}\text { Used to determine severity } \\
\text { of AOM for both } \\
\text { symptomatic and } \\
\text { otoscopic conditions. } \\
\text { Routine analysis of } \\
\text { tympanic membrane, bulla } \\
\text { formation, hemorrhagic } \\
\text { redness, and } \\
\text { purulent effusion. }\end{array}$ & $\begin{array}{l}\text { This clinical trial helped to } \\
\text { understand the severity and } \\
\text { symptoms of uni-/bi-lateral AOM in } \\
\text { children aged } 6 \text { to } 35 \text { months. } \\
\text { Assessment revealed that bilateral } \\
\text { AOM was more severe than } \\
\text { unilateral AOM. }\end{array}$ & 232 (children) & $\begin{array}{c}\text { Uitti et al. } \\
\text { [91] }\end{array}$ \\
\hline Tympanometry & 0 & $\begin{array}{l}\text { Used to assess the effect of } \\
\text { tympanometry on diagnosis } \\
\text { of otitis media. }\end{array}$ & $\begin{array}{l}\text { A randomized trial was conducted } \\
\text { to understand physician diagnosis } \\
\text { and prescription for OM when } \\
\text { using either a tympanometry } \\
\text { (specific to the middle ear) or an } \\
\text { otoscope (sees all the ear). The } \\
\text { study revealed that antibiotics were } \\
\text { prescribed for OM in both cases. }\end{array}$ & 698 (children) & $\begin{array}{c}\text { Spiro et al. } \\
\text { [92] }\end{array}$ \\
\hline $\begin{array}{l}\text { Tympanometry } \\
\text { with otoscope }\end{array}$ & 0 & $\begin{array}{l}\text { Used to compare the } \\
\text { effectiveness of } \\
\text { tympanometry with respect } \\
\text { to pneumatic otoscopy. }\end{array}$ & $\begin{array}{l}\text { The clinical trial study showed that } \\
\text { tympanometry could be used as an } \\
\text { adjunctive device with pneumatic } \\
\text { otoscopy and not as a standalone } \\
\text { device. }\end{array}$ & 515 (children) & $\begin{array}{l}\text { Helenius } \\
\text { et al. [93] }\end{array}$ \\
\hline $\begin{array}{l}\text { Optical } \\
\text { coherence } \\
\text { tomography }\end{array}$ & O & $\begin{array}{l}\text { Used for ear canal imaging } \\
\text { of the human tympanic } \\
\text { membrane to identify } \\
\text { epithelial and collagenous } \\
\text { layers and quantify } \\
\text { their thickness. }\end{array}$ & $\begin{array}{l}\text { The OCT clinical trials provided a } \\
\text { non-invasive means to study the } \\
\text { middle ear microstructure in vivo } \\
\text { utilizing a safe near-infrared light } \\
\text { source. Advantages include the } \\
\text { ability to image diseased tissues } \\
\text { with high resolution. }\end{array}$ & 10 (adults) & $\begin{array}{l}\text { Djalilian } \\
\text { et al. [94] }\end{array}$ \\
\hline $\begin{array}{l}\text { Optical } \\
\text { coherence } \\
\text { tomography }\end{array}$ & 0 & $\begin{array}{l}\text { Used for measuring the } \\
\text { optical properties of the } \\
\text { tympanic membrane. } \\
\text { Handheld, easy to use, for } \\
\text { noninvasive } \\
\text { routine analysis. }\end{array}$ & $\begin{array}{l}\text { The biofilm thickness results from } \\
\text { the OCT clinical trials revealed a } \\
\text { statistically significant quantitative } \\
\text { difference between normal, acute, } \\
\text { and chronic otitis media (OM) } \\
\text { infections. }\end{array}$ & 34 (children) & $\begin{array}{c}\text { Monroy et } \\
\text { al. [24] }\end{array}$ \\
\hline $\begin{array}{l}\text { Combination of } \\
\text { low-coherence } \\
\text { interferometry } \\
\text { and optical } \\
\text { coherence } \\
\text { tomography }\end{array}$ & 0 & $\begin{array}{l}\text { For proper diagnosis and } \\
\text { visualization of the } \\
\text { tympanic membrane with } \\
\text { and without biofilm growth. }\end{array}$ & $\begin{array}{l}\text { The clinical findings from the OCT } \\
\text { image scans in adults with chronic } \\
\text { OM indicated the formation of } \\
\text { biofilms as opposed to no biofilms } \\
\text { in healthy subjects. }\end{array}$ & 20 (adult) & $\begin{array}{l}\text { Nguyen } \\
\text { et al. [1] }\end{array}$ \\
\hline $\begin{array}{l}\text { Optical } \\
\text { coherence } \\
\text { tomography }\end{array}$ & 0 & $\begin{array}{l}\text { Used to observe effusion of } \\
\text { otitis media infected areas } \\
\text { based on the axial } \\
\text { depth scan. }\end{array}$ & $\begin{array}{l}\text { Spectral domain-OCT }(840 \mathrm{~nm}) \text { was } \\
\text { utilized to acquire axial depth scan } \\
\text { images from normal and healthy ear } \\
\text { to understand the OM infections. } \\
\text { These OCT image databases could } \\
\text { potentially serve as a means to } \\
\text { upgrade the current otoscopic } \\
\text { techniques. }\end{array}$ & $\begin{array}{c}39 \\
\text { (non-specified) }\end{array}$ & $\begin{array}{c}\text { Cho et al. } \\
\text { [95] }\end{array}$ \\
\hline $\begin{array}{l}\text { Confocal laser } \\
\text { scanning } \\
\text { microscopy } \\
\text { (CLSM) }\end{array}$ & O & $\begin{array}{l}\text { Used for identification of } \\
\text { biofilm growth from otitis } \\
\text { media and middle-ear } \\
\text { mucosa (MEM) } \\
\text { biopsy specimens. }\end{array}$ & $\begin{array}{l}\text { The CLSM mucosal biofilm images, } \\
\text { collected in this clinical study, } \\
\text { revealed that chronic OM in } \\
\text { humans is biofilm related. }\end{array}$ & 26 (children) & $\begin{array}{l}\text { Hall } \\
\text { Stoodley } \\
\text { [19] }\end{array}$ \\
\hline
\end{tabular}




\section{Conclusions}

This review summarized the literature regarding clinical and preclinical imaging techniques used for optical identification of middle ear infections. Clinical methods of investigating infections using a conventional otoscope, tympanometry, and optical coherence tomography were discussed along with their advantages and limitations. The list of clinical trial further presented the current medical devices used to diagnose middle ear infections. Furthermore, novel preclinical approaches and information on non-invasive Raman spectroscopy techniques for the detection of middle ear infection were presented to provide an outline of the current literature and to create a guideline for future progress. Although these non-invasive techniques are promising, future work should be directed to conducting clinical trials for these emerging imaging techniques to combat the suspected inefficiency in the current otologic diagnosis and help with the accurate treatment of middle ear infection decision making.

Author Contributions: Conceptualization, M.R.G., A.P., and S.M.A.H; writing, original draft preparation, review and editing, A.P. and S.M.A.H.; supervision, M.R.G.; funding acquisition, M.R.G. All authors have read and agreed to the published version of the manuscript.

Funding: A.P. was supported by the Louisiana Board of Regents Support Fund (RCS Award Contract Number: LEQSF (2017-20)-RD-A-04). M.R.G. acknowledges the support from LaSPACE REA SSC (Award No. AWDC-001589).

Conflicts of Interest: The authors declare no conflict of interest.

\section{References}

1. Nguyen, C.T.; Jung, W.; Kim, J.; Chaney, E.J.; Novak, M.; Stewart, C.N.; Boppart, S.A. Noninvasive in vivo optical detection of biofilm in the human middle ear. Proc. Natl. Acad. Sci. USA 2012, 109, 9529-9534. [CrossRef] [PubMed]

2. Klein, J.O. Otitis media. Clin. Infect. Dis. 1994, 19, 823-832. [CrossRef] [PubMed]

3. Roberts, J.E.; Rosenfeld, R.M.; Zeisel, S.A. Otitis media and speech and language: A meta-analysis of prospective studies. Pediatrics 2004, 113, e238-e248. [CrossRef] [PubMed]

4. Klein, J.O. The burden of otitis media. Vaccine 2000, 19, S2-S8. [CrossRef]

5. Harmes, K.; Blackwood, R.A.; Burrows, H.; Cooke, J.M.; Van Harrison, R.; Passamani, P. Otitis media: Diagnosis and treatment. Am. Fam. Physician 2013, 88, 435-440.

6. Heikkinen, T.; Thint, M.; Chonmaitree, T. Prevalence of various respiratory viruses in the middle ear during acute otitis media. N. Engl. J. Med. 1999, 340, 260-264. [CrossRef]

7. Stool, S.E.; Field, M.J. The impact of otitis media. Pediatric Infect. Dis. J. 1989, 8, S11-S14. [CrossRef]

8. Ahmed, S.; Shapiro, N.L.; Bhattacharyya, N. Incremental health care utilization and costs for acute otitis media in children. Laryngoscope 2014, 124, 301-305. [CrossRef]

9. Zhang, H.; Huang, J.; Li, T.; Svanberg, S.; Svanberg, K. Optical detection of middle ear infection using spectroscopic techniques: Phantom experiments. J. Biomed. Opt. 2015, 20, 057001. [CrossRef]

10. Bluestone, C.D.; Klein, J.O. Otitis Media in Infants and Children; PMPH: North Carolona, USA, 2007.

11. Dicks, L.; Knoetze, H.; Van Reenen, C. Otitis media: A review, with a focus on alternative treatments. Probiotics Antimicrob. Proteins 2009, 1, 45-59. [CrossRef]

12. Maxson, S.; Yamauchi, T. Acute otitis media. Pediatrics Rev. 1996, 17, 191. [CrossRef]

13. Kubba, H.; Pearson, J.; Birchall, J. The aetiology of otitis media with effusion: A review. Clin. Otolaryngol. Allied Sci. 2000, 25, 181-194. [CrossRef] [PubMed]

14. Lieberthal, A.S.; Carroll, A.E.; Chonmaitree, T.; Ganiats, T.G.; Hoberman, A.; Jackson, M.A.; Joffe, M.D.; Miller, D.T.; Rosenfeld, R.M.; Sevilla, X.D. The diagnosis and management of acute otitis media. Pediatrics 2013, 131, e964-e999. [CrossRef] [PubMed]

15. Tonnaer, E.L.; Graamans, K.; Sanders, E.A.; Curfs, J.H. Advances in understanding the pathogenesis of pneumococcal otitis media. Pediatric Infect. Dis. J. 2006, 25, 546-552. [CrossRef] [PubMed]

16. Reid, S.D.; Hong, W.; Dew, K.E.; Winn, D.R.; Pang, B.; Watt, J.; Glover, D.T.; Hollingshead, S.K.; Swords, W.E. Streptococcus pneumoniae forms surface-attached communities in the middle ear of experimentally infected chinchillas. J. Infect. Dis. 2009, 199, 786-794. [CrossRef] [PubMed] 
17. Cappelletty, D. Microbiology of bacterial respiratory infections. Pediatric Infect. Dis. J. 1998, 17, S55-S61. [CrossRef]

18. Del Beccaro, M.A.; Mendelman, P.M.; Inglis, A.F.; Richardson, M.A.; Duncan, N.O.; Clausen, C.R.; Stull, T.L. Bacteriology of acute otitis media: A new perspective. J. Pediatrics 1992, 120, 81-84. [CrossRef]

19. Hall-Stoodley, L.; Hu, F.Z.; Gieseke, A.; Nistico, L.; Nguyen, D.; Hayes, J.; Forbes, M.; Greenberg, D.P.; Dice, B.; Burrows, A. Direct detection of bacterial biofilms on the middle-ear mucosa of children with chronic otitis media. JAMA 2006, 296, 202-211. [CrossRef]

20. Ayala, O.D.; Wakeman, C.A.; Skaar, E.P.; Mahadevan-Jansen, A. Identification of bacteria causing acute otitis media using Raman microspectroscopy. In Biomedical Vibrational Spectroscopy 2016: Advances in Research and Industry; International Society for Optics and Photonics; San Francisco, CA, USA, 2016; p. 97040 U.

21. Holm, M.M.; Vanlerberg, S.L.; Sledjeski, D.D.; Lafontaine, E.R. The Hag protein of Moraxella catarrhalis strain O35E is associated with adherence to human lung and middle ear cells. Infect. Immun. 2003, 71, 4977-4984. [CrossRef]

22. Ludman, H.S.; Bradley, P.J. ABC of Ear, Nose and Throat; John Wiley \& Sons: Hoboken, NJ, USA, 2012; Volume 254.

23. Mittal, R.; Lisi, C.V.; Gerring, R.; Mittal, J.; Mathee, K.; Narasimhan, G.; Azad, R.K.; Yao, Q.; Grati, M.H.; Yan, D. Current concepts in the pathogenesis and treatment of chronic suppurative otitis media. J. Med. Microbiol. 2015, 64, 1103. [CrossRef]

24. Monroy, G.L.; Shelton, R.L.; Nolan, R.M.; Nguyen, C.T.; Novak, M.A.; Hill, M.C.; McCormick, D.T.; Boppart, S.A. Noninvasive depth-resolved optical measurements of the tympanic membrane and middle ear for differentiating otitis media. Laryngoscope 2015, 125, E276-E282. [CrossRef] [PubMed]

25. Jones, W.S.; Kaleida, P.H. How helpful is pneumatic otoscopy in improving diagnostic accuracy? Pediatrics 2003, 112, 510-513. [CrossRef] [PubMed]

26. Moshtaghi, O.; Sahyouni, R.; Haidar, Y.M.; Huang, M.; Moshtaghi, A.; Ghavami, Y.; Lin, H.W.; Djalilian, H.R. Smartphone-enabled otoscopy in neurotology/otology. Otolaryngol. Head Neck Surg. 2017, 156, 554-558. [CrossRef] [PubMed]

27. Bhavana, K.; Ahmad, M.; Sharma, P. Smartphone Otoscopy Sans Attachment: A Paradigm Shift in Diagnosing Ear Pathologies. OTO Open 2018, 2, 2473974X18786496. [CrossRef] [PubMed]

28. Son, J.H.; Oh, S.J.; Cheon, H. Potential clinical applications of terahertz radiation. J. Appl. Phys. 2019, 125, 190901. [CrossRef]

29. D'Arco, A.; Di Fabrizio, M.; Dolci, V.; Petrarca, M.; Lupi, S. THz Pulsed Imaging in Biomedical Applications. Condens. Matter 2020, 5, 25. [CrossRef]

30. Reid, C.B.; Fitzgerald, A.; Reese, G.; Goldin, R.; Tekkis, P.; O’Kelly, P.; Pickwell-MacPherson, E.; Gibson, A.P.; Wallace, V.P. Terahertz pulsed imaging of freshly excised human colonic tissues. Phys. Med. Biol. 2011, 56, 4333. [CrossRef]

31. Teppo, H.; Revonta, M.; Lindén, H.; Palmu, A. Detection of middle-ear fluid in children with spectral gradient acoustic reflectometry: A screening tool for nurses? Scand. J. Prim. Health Care 2006, 24, 88-92. [CrossRef]

32. Shekelle, P.; Takata, G.; Chan, L.S.; Mangione-Smith, R.; Corley, P.M.; Morphew, T.; Morton, S. Diagnosis, natural history, and late effects of otitis media with effusion. Evid. Rep./Technol. Assess. 2002, 55, 1.

33. Palmu, A.; Puhakka, H.; Rahko, T.; Takala, A.K. Diagnostic value of tympanometry in infants in clinical practice. Int. J. Pediatric Otorhinolaryngol. 1999, 49, 207-213. [CrossRef]

34. Watters, G.; Jones, J.; Freeland, A. The predictive value of tympanometry in the diagnosis of middle ear effusion. Clin. Otolaryngol. Allied Sci. 1997, 22, 343-345. [CrossRef] [PubMed]

35. Sundvall, P.D.; Papachristodoulou, C.E.; Nordeman, L. Diagnostic methods for acute otitis media in 1 to 12 year old children: A cross sectional study in primary health care. BMC Fam. Pract. 2019, 20, 127. [CrossRef] [PubMed]

36. Nguyen, C.T.; Tu, H.; Chaney, E.J.; Stewart, C.N.; Boppart, S.A. Non-invasive optical interferometry for the assessment of biofilm growth in the middle ear. Biomed. Opt. Express 2010, 1, 1104-1116. [CrossRef] [PubMed]

37. Evers, D.J.; Nachabé, R.; Klomp, H.M.; van Sandick, J.W.; Wouters, M.W.; Lucassen, G.W.; Hendriks, B.H.; Wesseling, J.; Ruers, T.J. Diffuse reflectance spectroscopy: A new guidance tool for improvement of biopsy procedures in lung malignancies. Clin. Lung Cancer 2012, 13, 424-431. [CrossRef] [PubMed] 
38. Jayanthi, J.; Nisha, G.; Manju, S.; Philip, E.; Jeemon, P.; Baiju, K.; Beena, V.; Subhash, N. Diffuse reflectance spectroscopy: Diagnostic accuracy of a non-invasive screening technique for early detection of malignant changes in the oral cavity. BMJ Open 2011, 1, e000071. [CrossRef] [PubMed]

39. Lucchi, N.W.; Demas, A.; Narayanan, J.; Sumari, D.; Kabanywanyi, A.; Kachur, S.P.; Barnwell, J.W.; Udhayakumar, V. Real-time fluorescence loop mediated isothermal amplification for the diagnosis of malaria. PLOS ONE 2010, 5, e13733. [CrossRef]

40. Preciado, D.; Nolan, R.M.; Joshi, R.; Krakovsky, G.M.; Zhang, A.; Pudik, N.A.; Kumar, N.K.; Shelton, R.L.; Boppart, S.A.; Bauman, N.M. Otitis Media Middle Ear Effusion Identification and Characterization Using an Optical Coherence Tomography Otoscope. Otolaryngol. Head Neck Surg. 2020, 162, 367-374. [CrossRef]

41. Große-Stoltenberg, A.; Hellmann, C.; Werner, C.; Oldeland, J.; Thiele, J. Evaluation of continuous VNIR-SWIR spectra versus narrowband hyperspectral indices to discriminate the invasive Acacia longifolia within a Mediterranean dune ecosystem. Remote Sens. 2016, 8, 334. [CrossRef]

42. Gerger, A.; Koller, S.; Kern, T.; Massone, C.; Steiger, K.; Richtig, E.; Kerl, H.; Smolle, J. Diagnostic applicability of in vivo confocal laser scanning microscopy in melanocytic skin tumors. J. Investig. Dermatol. 2005, 124, 493-498. [CrossRef]

43. Gerger, A.; Koller, S.; Weger, W.; Richtig, E.; Kerl, H.; Samonigg, H.; Krippl, P.; Smolle, J. Sensitivity and specificity of confocal laser-scanning microscopy for in vivo diagnosis of malignant skin tumors. Cancer 2006, 107, 193-200. [CrossRef]

44. Principi, N.; Esposito, S.; Cavagna, R.; Bosis, S.; Droghetti, R.; Faelli, N.; Tosi, S.; Begliatti, E.; Group, S.S. Recurrent respiratory tract infections in pediatric age: A population-based survey of the therapeutic role of macrolides. J. Chemother. 2003, 15, 53-59. [CrossRef] [PubMed]

45. Nazzari, E.; Torretta, S.; Pignataro, L.; Marchisio, P.; Esposito, S. Role of biofilm in children with recurrent upper respiratory tract infections. Eur. J. Clin. Microbiol. Infect. Dis. 2015, 34, 421-429. [CrossRef] [PubMed]

46. Yang, R.; Sabharwal, V.; Okonkwo, O.S.; Shlykova, N.; Tong, R.; Lin, L.Y.; Wang, W.; Guo, S.; Rosowski, J.J.; Pelton, S.I. Treatment of otitis media by transtympanic delivery of antibiotics. Sci. Transl. Med. 2016, 8, ra120-ra356. [CrossRef] [PubMed]

47. Ji, Y.B.; Moon, I.S.; Bark, H.S.; Kim, S.H.; Park, D.W.; Noh, S.K.; Huh, Y.M.; Suh, J.S.; Oh, S.J.; Jeon, T.I. Terahertz otoscope and potential for diagnosing otitis media. Biomed. Opt. Express 2016, 7, 1201-1209. [CrossRef] [PubMed]

48. Morris, E.; Kesser, B.W.; Peirce-Cottler, S.; Keeley, M. Development and validation of a novel ear simulator to teach pneumatic otoscopy. Simul. Healthc. 2012, 7, 22-26. [CrossRef] [PubMed]

49. Dsouza, R.; Won, J.; Monroy, G.L.; Hill, M.C.; Porter, R.G.; Novak, M.A.; Boppart, S.A. In vivo detection of nanometer-scale structural changes of the human tympanic membrane in otitis media. Sci. Rep. 2018, 8, 1-13. [CrossRef]

50. Chaichi, A.; Prasad, A.; Gartia, M. Raman Spectroscopy and Microscopy Applications in Cardiovascular Diseases: From Molecules to Organs. Biosensors 2018, 8, 107. [CrossRef]

51. Jarvis, R.M.; Goodacre, R. Discrimination of bacteria using surface-enhanced Raman spectroscopy. Anal. Chem. 2004, 76, 40-47. [CrossRef]

52. Goodacre, R.; Timmins éadaoin, M.; Burton, R.; Kaderbhai, N.; Woodward, A.M.; Kell, D.B.; Rooney, P.J. Rapid identification of urinary tract infection bacteria using hyperspectral whole-organism fingerprinting and artificial neural networks. Microbiology 1998, 144, 1157-1170. [CrossRef]

53. Maquelin, K.; Choo-Smith, L.P.I.; van Vreeswijk, T.; Endtz, H.P.; Smith, B.; Bennett, R.; Bruining, H.A.; Puppels, G.J. Raman spectroscopic method for identification of clinically relevant microorganisms growing on solid culture medium. Anal. Chem. 2000, 72, 12-19. [CrossRef]

54. Schuster, K.C.; Reese, I.; Urlaub, E.; Gapes, J.R.; Lendl, B. Multidimensional information on the chemical composition of single bacterial cells by confocal Raman microspectroscopy. Anal. Chem. 2000, 72, 5529-5534. [CrossRef] [PubMed]

55. Pandey, R.; Paidi, S.K.; Kang, J.W.; Spegazzini, N.; Dasari, R.R.; Valdez, T.A.; Barman, I. Discerning the differential molecular pathology of proliferative middle ear lesions using Raman spectroscopy. Sci. Rep. 2015, 5, 13305. [CrossRef] [PubMed] 
56. Zhao, Y.; Monroy, G.L.; You, S.; Shelton, R.L.; Nolan, R.M.; Tu, H.; Chaney, E.J.; Boppart, S.A. Rapid diagnosis and differentiation of microbial pathogens in otitis media with a combined Raman spectroscopy and low-coherence interferometry probe: Toward in vivo implementation. J. Biomed. Opt. 2016, 21, 107005. [CrossRef] [PubMed]

57. Rebrošová, K.; Šiler, M.; Samek, O.; Růžička, F.; Bernatová, S.; Holá, V.; Ježek, J.; Zemánek, P.; Sokolová, J.; Petráš, P. Rapid identification of staphylococci by Raman spectroscopy. Scientific reports 2017, 7, 14846. [CrossRef] [PubMed]

58. Jung, G.B.; Nam, S.W.; Choi, S.; Lee, G.J.; Park, H.K. Evaluation of antibiotic effects on Pseudomonas aeruginosa biofilm using Raman spectroscopy and multivariate analysis. Biomed. Opt. Express 2014, 5, 3238-3251. [CrossRef]

59. Kamińska, A.; Witkowska, E.; Kowalska, A.; Skoczyńska, A.; Ronkiewicz, P.; Szymborski, T.; Waluk, J. Rapid detection and identification of bacterial meningitis pathogens in ex vivo clinical samples by SERS method and principal component analysis. Anal. Methods 2016, 8, 4521-4529. [CrossRef]

60. Pahlow, S.; Stöckel, S.; Pollok, S.; Cialla-May, D.; Rösch, P.; Weber, K.; Popp, J.R. Rapid identification of Pseudomonas spp. via Raman spectroscopy using pyoverdine as capture probe. Anal. Chem. 2016, 88, 1570-1577. [CrossRef]

61. Dostál, L.; Misselwitz, R.; Laettig, S.; Alonso, J.C.; Welfle, H. Raman spectroscopy of regulatory protein Omega from Streptococcus pyogenes plasmid pSM19035 and complexes with operator DNA. J. Spectrosc. 2003, 17, 435-445. [CrossRef]

62. Khalid, M.; Bora, T.; Al Ghaithi, A.; Thukral, S.; Dutta, J. Raman spectroscopy detects changes in bone mineral quality and collagen cross-linkage in staphylococcus infected human bone. Sci. Rep. 2018, 8, 1-9. [CrossRef]

63. Sil, S.; Mukherjee, R.; Kumar, N.; Aravind, S.; Kingston, J.; Singh, U. Detection and classification of bacteria using Raman spectroscopy combined with multivariate analysis. Def. Life Sci. J. 2017, 2, 435-441. [CrossRef]

64. Meisel, S.; Stöckel, S.; Rösch, P.; Popp, J. Identification of meat-associated pathogens via Raman microspectroscopy. Food Microbiol. 2014, 38, 36-43. [CrossRef] [PubMed]

65. Hamasha, K.M. Raman Spectroscopy for the Microbiological Characterization and Identification of Medically Relevant Bacteria; Digital Commons@WayneState: Detroit, MI, USA, 2011.

66. Pandey, R.; Valdez, T.A. Chemical Imaging in Middle Ear Pathology: Quo Vadis? J. Postdr. Res. Jan. 2016, 7, 12. [CrossRef]

67. Ayala, O.D.; Wakeman, C.A.; Pence, I.J.; Gaddy, J.A.; Slaughter, J.C.; Skaar, E.P.; Mahadevan-Jansen, A. Drug-resistant Staphylococcus aureus strains reveal distinct biochemical features with Raman microspectroscopy. ACS Infect. Dis. 2018, 4, 1197-1210. [CrossRef] [PubMed]

68. Boppart, S.A.; Shelton, R.L. Handheld Device for Identification of Microbiological Constituents in the Middle Ear. U.S. Patent Application No. 16/012,201, 25 October 2018.

69. Sundberg, M.; Peebo, M.; Öberg, P.Å.; Lundquist, P.G.; Strömberg, T. Diffuse reflectance spectroscopy of the human tympanic membrane in otitis media. Physiol. Meas. 2004, 25, 1473. [CrossRef] [PubMed]

70. Keefe, D.H. Acoustical transmission-line model of the middle-ear cavities and mastoid air cells. J. Acoust. Soc. Am. 2015, 137, 1877-1887. [CrossRef]

71. Ars, B.; Dirckx, J.; Ars-Piret, N.; Buytaert, J. Insights in the physiology of the human mastoid: Message to the surgeon. J. Int. Adv. Otol. 2012, 8, 296.

72. Hu, L.; Li, W.; Lin, H.; Li, Y.; Zhang, H.; Svanberg, K.; Svanberg, S. Towards an optical diagnostic system for otitis media using a combination of otoscopy and spectroscopy. J. Biophotonics 2019, 12, e201800305. [CrossRef]

73. Valdez, T.A.; Pandey, R.; Spegazzini, N.; Longo, K.; Roehm, C.; Dasari, R.R.; Barman, I. Multiwavelength fluorescence otoscope for video-rate chemical imaging of middle ear pathology. Anal. Chem. 2014, 86, 10454-10460. [CrossRef]

74. Coticchia, J.M.; Chen, M.; Sachdeva, L.; Mutchnick, S. New paradigms in the pathogenesis of otitis media in children. Front. Pediatrics 2013, 1, 52. [CrossRef]

75. Huang, D.; Swanson, E.A.; Lin, C.P.; Schuman, J.S.; Stinson, W.G.; Chang, W.; Hee, M.R.; Flotte, T.; Gregory, K.; Puliafito, C.A. Optical coherence tomography. Science 1991, 254, 1178-1181. [CrossRef]

76. Nguyen, C.T.; Robinson, S.R.; Jung, W.; Novak, M.A.; Boppart, S.A.; Allen, J.B. Investigation of bacterial biofilm in the human middle ear using optical coherence tomography and acoustic measurements. Hear. Res. 2013, 301, 193-200. [CrossRef] [PubMed] 
77. Jung, W.; Kim, J.; Jeon, M.; Chaney, E.J.; Stewart, C.N.; Boppart, S.A. Handheld optical coherence tomography scanner for primary care diagnostics. IEEE Trans. Biomed. Eng. 2011, 58, 741-744. [CrossRef] [PubMed]

78. Shelton, R.L.; Jung, W.; Sayegh, S.I.; McCormick, D.T.; Kim, J.; Boppart, S.A. Optical coherence tomography for advanced screening in the primary care office. J. Biophotonics 2014, 7, 525-533. [CrossRef] [PubMed]

79. Fercher, A.F. Optical coherence tomography. J. Biomed. Opt. 1996, 1, 157-174. [CrossRef]

80. Boppart, S.A.; Xi, C. Device and Method for Imaging the Ear Using Optical Coherence Tomography. U.S. Patent No. 8,115,934, 14 February 2012.

81. Carr, J.A.; Valdez, T.A.; Bruns, O.T.; Bawendi, M.G. Using the shortwave infrared to image middle ear pathologies. Proc. Natl. Acad. Sci. USA 2016, 113, 9989-9994. [CrossRef] [PubMed]

82. Schaefer, A.; Cook, N.; Tessaro, S.; Deregt, D.; Desroches, G.; Dubeski, P.; Tong, A.; Godson, D. Early detection and prediction of infection using infrared thermography. Can. J. Anim. Sci. 2004, 84, 73-80. [CrossRef]

83. Tang, E.N.; Nair, A.; Baker, D.W.; Hu, W.; Zhou, J. In vivo imaging of infection using a bacteria-targeting optical nanoprobe. J. Biomed. Nanotechnol. 2014, 10, 856-863. [CrossRef]

84. Hoa, M.; Tomovic, S.; Nistico, L.; Hall-Stoodley, L.; Stoodley, P.; Sachdeva, L.; Berk, R.; Coticchia, J.M. Identification of adenoid biofilms with middle ear pathogens in otitis-prone children utilizing SEM and FISH. Int. J. Pediatric Otorhinolaryngol. 2009, 73, 1242-1248. [CrossRef]

85. Saafan, M.E.; Ibrahim, W.S.; Tomoum, M.O. Role of adenoid biofilm in chronic otitis media with effusion in children. Eur. Arch. Oto-Rhino-Laryngol. 2013, 270, 2417-2425. [CrossRef]

86. Boppart, S.A.; Richards-Kortum, R. Point-of-care and point-of-procedure optical imaging technologies for primary care and global health. Sci. Transl. Med. 2014, 6, rv252-rv253. [CrossRef]

87. Richards, J.R.; Gaylor, K.A.; Pilgrim, A.J. Comparison of traditional otoscope to iPhone otoscope in the pediatric ED. Am. J. Emerg. Med. 2015, 33, 1089-1092. [CrossRef] [PubMed]

88. Shaikh, N.; Hoberman, A.; Paradise, J.L.; Wald, E.R.; Switze, G.E.; Kurs-Lasky, M.; Colborn, D.K.; Kearney, D.H.; Zoffel, L.M. Development and preliminary evaluation of a parent-reported outcome instrument for clinical trials in acute otitis media. Pediatric Infect. Dis. J. 2009, 28, 5-8. [CrossRef] [PubMed]

89. Shaikh, N.; Hoberman, A.; Kaleida, P.H.; Rockette, H.E.; Kurs-Lasky, M.; Hoover, H.; Pichichero, M.E.; Roddey, O.F.; Harrison, C.; Hadley, J.A. Otoscopic signs of otitis media. Pediatric Infect. Dis. J. 2011, 30, 822-826. [CrossRef] [PubMed]

90. Cavanaugh, R.M. Pneumatic otoscopy in healthy full-term infants. Pediatrics 1987, 79, 520-523. [PubMed]

91. Uitti, J.M.; Laine, M.K.; Tähtinen, P.A.; Ruuskanen, O.; Ruohola, A. Symptoms and otoscopic signs in bilateral and unilateral acute otitis media. Pediatrics 2013, 131, e398-e405. [CrossRef] [PubMed]

92. Spiro, D.M.; King, W.D.; Arnold, D.H.; Johnston, C.; Baldwin, S. A randomized clinical trial to assess the effects of tympanometry on the diagnosis and treatment of acute otitis media. Pediatrics 2004, 114, 177-181. [CrossRef]

93. Helenius, K.K.; Laine, M.K.; Tähtinen, P.A.; Lahti, E.; Ruohola, A. Tympanometry in discrimination of otoscopic diagnoses in young ambulatory children. Pediatric Infect. Dis. J. 2012, 31, 1003-1006. [CrossRef]

94. Djalilian, H.R.; Ridgway, J.; Tam, M.; Sepehr, A.; Chen, Z.; Wong, B.J. Imaging the human tympanic membrane using optical coherence tomography in vivo. Otol. Neurotol. 2008, 29, 1091. [CrossRef]

95. Cho, N.H.; Lee, S.H.; Jung, W.; Jang, J.H.; Kim, J. Optical coherence tomography for the diagnosis and evaluation of human otitis media. J. Korean Med. Sci. 2015, 30, 328-335. [CrossRef]

(C) 2020 by the authors. Licensee MDPI, Basel, Switzerland. This article is an open access article distributed under the terms and conditions of the Creative Commons Attribution (CC BY) license (http://creativecommons.org/licenses/by/4.0/). 